\title{
INTRA-EU CROSS-BORDER PLATFORM WORK: HIDING ISSUES OF UNDECLARED WORK
}

The aim of this paper is to demonstrate that cross-border platform work raises specific issues with regard to undeclared work understood as income which is totally or partially declared in a country by the cross-border platform worker for the purpose and/or with the result of evading the law of another country. The complexity of EU regulations applying to cross-border situations and the lack of efficient information-sharing processes between countries enhance the risks of this form of undeclared work by platform workers both from the perspectives of social security law and of labour law. The question whether rules determining the social security legislation applicable under Regulation (EC) No 883/2004 are in line with rules on free movement of services is also discussed.

Key words: cross-border platform work; undeclared work; Regulation 883/2004; Regulation (EC) No 593/2008; free movement of services

* Dr. Jean-Philippe Lhernould, Professor, Faculty of Law and Social Sciences, University of Poitiers, 2 rue Jean Carbonnier - Bât A I - TSA 81100, 86073 Poitiers Cedex 9, France; jean-philippe.lhernould@univ-poitiers.fr;

ORCID ID: orcid.org/0000-0001-7871-1353 


\section{INTRODUCTION}

\subsection{Undeclared work: current challenges in the light of platform work}

Although not being an official definition, at the EU level, undeclared work is commonly understood as meaning 'any paid activities that are lawful as regards their nature, but are not declared to the public authorities, taking into account the differences in the regulatory systems of the Member States.'

Undeclared work raises important political challenges. ${ }^{2}$ First, tax authorities receive less revenue in the form of income tax or value added taxes. Moreover, social security institutions do not receive the necessary contributions. As a result, undeclared work risks to undermine the fiscal sustainability of public finances in general and social security systems in particular. Second, the undeclared worker often faces poor working conditions, deficits in terms of health and safety requirements, low income and no or inadequate social protection. Lastly, undeclared work functions as a distorting factor and prevents fair competition.

Most findings suggest that undeclared work is often carried out in sectors like construction, renovation or repair works, cleaning, babysitting or care for the elderly. ${ }^{3}$ Many of these sectors are very prevalent in the platform economy and concern services which are provided on location by the platform workers. The Eurobarometer on 'Undeclared Work in the European Union' has suggested a greater tendency to supply undeclared work among 15-34 years old, people who struggle with household bills, the unemployed and students. ${ }^{4}$ Again, many of these social strata are very active in the platform economy as platform workers (15-34 years old, students, poorer segments of society). Platform work is still primarily performed as a second(ary) 'job' and the income generated through platform work is usually not the main source of income of the platform worker. The features that are characteristic for platform work such as the fragmentation

1 European Commission Communication 'Stepping up the fight against undeclared work', $\operatorname{COM}(2007)$ 628, p. 2.

2 European Commission, European Semester Thematic Factsheet on Undeclared Work https://ec.europa.eu/info/sites/info/files/file_import/european-semester_thematicfactsheet_undeclared-work_en.pdf.

3 European Commission, Special Eurobarometer 402 "Undeclared Work in the European Union”, March 2014, pp. 121 - 122; Popescu, M.; Cristescu, A.; Stanila, L.; Vasiles$\mathrm{cu}$, M., Determinants of undeclared work in the EU Member States, Procedia Economics and Finance, vol. 39, 2016, pp. 520 - 525.

4 European Commission, Special Eurobarometer 402 "Undeclared Work in the European Union”, March 2014, pp. 121 - 122; Popescu, M. et al., op. cit. (fn. 3). 
and piecemeal provision of services, small scale size of the work assignments, individualistic nature of the service delivery, exclusive online relationship with the platform and absence of a common working place and social control are all factors which seem to contribute to the fact that platform work services can more easily be delivered in a hidden and unreported way. The lack of data and statistics concerning platform work practices, especially those that are delivered online, make a robust analysis nearly impossible.

There are several socioeconomic trends which are increasing the scale of undeclared work today. The European Semester Thematic Factsheet on Undeclared Work lists the following : growing flexibility of contractual relationships, especially the increase in self-employed work, subcontracting and outsourcing; reorientation of the economy towards sectors most affected by undeclared work (household and care services); increase in social distress in some EU countries, with some people who might try to compensate income losses through undeclared work; growth of cross-border business, which requires efficient international cooperation between monitoring and enforcement bodies.

The platform economy is right in the middle of these socio-economic trends. ${ }^{6}$ Platform work is typically characterized by a very flexible contractual relation-

5 European Commission, European Semester Thematic Factsheet on Undeclared Work, https://ec.europa.eu/info/sites/info/files/file_import/european-semester_thematicfactsheet_undeclared-work_en.pdf.

6 Among many reports and studies, see European Economic and Social Committee, Impact of digitalisation and the on-demand economy on labour markets and the consequences for employment and industrial relations. Publications Office of the European Union, Luxembourg, Brussels, 2017, https://www.eesc.europa.eu/sites/default/files/resources/docs/qe-02-17-763-en-n.pdf; Eurofound, Automation, digitalisation and platforms: Implications for work and employment, Publications Office of the European Union, Luxembourg, 2018, https://www.eurofound.europa.eu/sites/default/files/ef_publication/field_ef_document/ef18002en.pdf; Eurofound, Employment and working conditions of selected types of platform work, Publications Office of the European Union, Luxembourg, 2018, https://www.eurofound.europa.eu/publications/report/2018/ employment-and-working-conditions-of-selected-types-of-platform-work; Florisson R.; Mandl, I., Platform work: Types and implications for work and employment, Literature review, Eurofound, 2018, https://www.eurofound.europa.eu/sites/default/files/ wpef 18004.pdf; Lhernould, J-Ph., Employment and working conditions of selected types of platform work: National context analysis France, Eurofound, 2018, https:/www.eurofound.europa.eu/sites/default/files/wpef18054.pdf; Pesole, A.; Urzí Brancati, M. C.; Fernández-Macías, E.; Biagi, F.; González Vázquez, I., Platform Workers in Europe, EUR 29275 EN, Publications Office of the European Union, Luxembourg, 2018, https://publications.jrc.ec.europa.eu/repository/bitstream/JRC112157/jrc112157_ pubsy_platform_workers_in_europe_science_for_policy.pdf. 
ship, whereby the platform worker is generally considered (by the platform) to be a self-employed person not rarely because of the lower costs and risks for the platforms which are operating in highly competitive markets. Moreover, the platform economy has a considerable and increasing stake in typical household and care services (e.g. child attending services, cleaning services). Platform work is often performed as a second activity and the income generated through platform work aimed at complementing the main source of income. Lastly, many platforms are transnational businesses, acting throughout the European Union and often beyond. At the same time, the platform workers can more easily access and perform cross-border platform work especially for services that are delivered online.

This last consideration brings us to the main focus of this paper which is concerned with the very specific dimension of undeclared work in cross-border services delivery facilitated by platforms. Our goal is to investigate the existence of specific undeclared work issues in cross-border platform work.

\subsection{What is platform work?}

The forms of platform work are diverse. The variety of situations explains that cross-platform work is less unusual than it seems. For the purpose of this paper, four categories of platform work will be identified.

First, 'platform work' includes work performed by a (taxi) driver carrying passengers or couriers delivering goods, where the platform initiates the distribution of work to the platform workers, independent of whether the effective payment by the end user or customer is channelled directly to the platform worker or via the platform business. It is usually performed by low skilled workers.

Second, 'platform work' refers to work performed by a person who works on-location of the end user or customer to perform services requiring low skills, e.g. domestic cleaning, babysitting, or dog walking, as well as work requiring more specialised training such as roofing, plumbing, electrical work, etc.

Third, 'platform work' encompasses low- or medium-skilled work such as data entry, clerical work, filling out surveys, tagging photographs, and other services, which are divided into very small units of work, and performed remotely and delivered online, usually referred to as click-work, or crowd-work. Workers are often called "clickworkers".

Finally, 'platform work' consists of high-skilled work such as graphic design, IT (software) development, or architecture, as well as counselling or advisory services (e.g. legal or medical), performed remotely and delivered online or otherwise remotely. In contrast with traditional self-employed professionals or 
freelancers, the supply and demand of these services is facilitated or managed entirely by a platform business.

Based on these four categories, cross-border platform work can take several shapes.

\subsection{When is there cross-border platform work?}

Based on the four categories descripted in point 1.2, cross-border platform work does exist and can take three shapes: the platform worker performs an activity in the home Member State of the European Union (hereafter "Member State") for an end user and/or platform situated in another Member State (1.3.1); the platform worker physically moves to another Member State to perform work either locally or to deliver a service to a foreign platform or end user (1.3.2); a platform worker is simultaneously employed in different Member States (1.3.3).

\subsubsection{Platform worker performing work in home Member State for platform and/or end user situated in another Member State}

In this situation the platform worker performs his/her activity in the home Member State but either the platform or the end user is located in another Member State. It seems relevant to first highlight the perspective of the platform itself, which although being largely contested by the platform businesses, could be considered as a service provider rendering services to the end user. CJEU settled case-law can be interpreted as meaning that temporary services which the provider (platform) carries out via platform workers without moving from the Member State in which they are established and for recipients (end users) established in other Member States constitute the provision of cross-border services for the purposes of Article 56 TFEU. ${ }^{7}$ Rules on free movement of services apply indeed to these triangular relationships. ${ }^{8}$ The fact that the service is provided via internet does not exclude the application of rules on free movement of services. ${ }^{9}$ Indeed, it is settled case-law that services which the provider carries out without moving from the Member State in which (s)he is established for recipients established in other Member States constitute a cross-border service. ${ }^{10}$

\footnotetext{
7 Judgment of the CJEU, Case C-384/93, Alpine Investments BV v. Minister van Financiën.

8 Judgment of the CJEU, Case 279/80, Alfred John Webb.

9 Judgment of the CJEU, Case C-243/01, Piergiorgio Gambelli and Others.

10 See CJEU Alpine Investments, op. cit.
} 
The following three situations can be distinguished.

First, the platform worker may perform his activity in his home Member State for an end user located in another Member State. This situation is especially relevant for the last two types of platform workers. For instance, a graphic designer may design a logo online in his home Member State for a company located in another Member State.

Second, the platform worker and the end user are situated in the same (home) Member State whilst the platform is established in another one (maybe even a non-EU country). All four types of platform workers can fit into this example. For instance, a cleaning person is registered as self-employed person in a country where he/she performs his/her activity for local clients via a platform established in another Member State. By the same token, a Click-worker can perform a small task (for a company which is located in the same (home) Member State) on a platform established in another Member State.

Finally, the platform worker performs his/her activity in his/her home Member State, but both the end user and platform are situated in another Member State. Once again, this situation seems to fit the last two types of platform work concerning online services. For example, a platform worker can give legal advice online in his home Member State on a platform established in another Member State to a company also located in another Member State.

\subsubsection{Platform worker physically moves to another Member State to perform an activity}

Here the platform worker physically moves to another Member State to perform his/her activity. Different possibilities can be envisaged.

First, the platform worker moves to another Member State to perform an activity for an end user located in that same Member State whilst the platform is located in yet another Member State. In theory, all four types of platform worker can apply here. Most likely however, it will be the first two types that are most common. For instance, a self-employed cleaning person moves to another Member State to perform his/her task locally.

Second, the platform worker moves to another Member State to perform an activity for an end user located in yet another Member State while the platform is established in the same Member State where the platform worker performs an activity. One reason for this might be that the platform worker is stimulated to move to a Member State where he/she is classified as an employee, or alternatively to a Member State which offers the highest protection to self-employed persons if the platform worker is treated as that. In this situation, the last two types will 
apply. For instance, a click-worker filling out surveys in a Member State other than his home Member State for a company located in yet another Member State.

Third, the platform worker physically moves to another Member State with both the end user and the platform being established in that same Member State. The four types will apply in this situation. For example, a delivery rider who moved to another Member State to perform an activity on a local platform.

Fourth, the platform worker physically moves to another Member State, but both the end user and the platform are located in yet another Member State. This is essentially a situation where the platform worker delivers a service to a foreign platform. The last two types of platform workers will apply here. For instance, a platform worker goes to another Member State to give online medical advice on a platform situated in yet another Member State.

\subsubsection{Platform worker is simultaneously working in different Member States}

In border areas, it is not unusual that workers carry out their professional activities in two or more countries. Let us give three examples. For instance, the platform worker performs one single activity for one company in two countries. $\mathrm{He}$ can therefore exercise a taxi driving activity in border countries A and $\mathrm{B}$ for the same platform. Another example is the case where the worker performs the same activity in two countries for two companies. For instance, a plumber exercises the platform activity in country A for platform A and in country B for platform B. He/she can also perform his activities in countries A and B for both platforms. Finally, the worker performs two activities, only one being through a platform. For example, the worker has a permanent job (with the employed or self-employed status) in country A but also performs via a platform a graphic design activity in country B.

\section{ARE THERE ANY SPECIFIC ISSUES CONCERNING CROSS-BORDER UNDECLARED PLATFORM WORK?}

\subsection{No visible issues of undeclared work}

To our knowledge, no European or national survey has put forward any issue concerning cross-border platform work and undeclared work. Furthermore, without any quantitative data available, it is hard to assess the exact nature and intensity of cross-border platform work as well as the potential issues. Still, the purpose of this paper is to identify some specific legal issues that have not been detected yet, but which are nonetheless important challenges. 
Undeclared work takes two well-known forms: income received may not be declared at all; income may be partially declared (under-declared work). Undeclared work includes non-compliance with 'either labour, tax and/or social security legislation or regulations.'. Undeclared self-employment refers to 'paid activity conducted by the self-employed where income is not declared for the purpose of evading either tax and/or social insurance contributions owed. The self-employed may not declare either some or all their income'.

Our assumption is that it is likely that such unlawful cases also occur in the context of cross-border platform work. If obstacles to tackling undeclared work at the cross-border level, which have been duly identified ${ }^{12}$, are probably relevant in the context of platform work, risks of non-compliance may be increased in the case of cross-border activity. For instance, if the platform is established in country A and the platform worker performs his activity in country B where he is registered, it could be easier for the worker not to declare income received through the platform. ${ }^{13}$ Likewise, it could be tempting (and feasible) for a platform worker who exercises his activity in at least two countries to hide income received in the country other than the one where he is registered and where taxes are paid. However, there is no statistical or empirical evidence of enhanced risks. Since platforms in practice require a prior self-employment registration from platform workers, cross-border platform workers and domestic platform workers could after all be roughly in the same situation vis-à-vis undeclared work.

We should now explore more precisely the risks at stake.

\subsection{Underlying issues of undeclared work?}

There is a need to read the usual undeclared work definitions recalled above in the context of cross-border platform activities. This paper will indeed focus on a specific variety of undeclared work: income which is totally or partially

11 Definition of undeclared work, European platform tackling undeclared work: https://ec.europa.eu/social/main.jsp?catId=1323\&langId=en\#chapter_U.

12 Barriers to or lack of data sharing, legal issues, inadequate resources (staff, funding, time, knowledge), language issues and difficulties in detecting undeclared work (see European Platform Undeclared Work, obstacles to tackling undeclared work at the cross-border and national levels, bilateral and national agreements, and complaint reporting tools, work survey report, 2018.

13 This could be true in countries where platforms must declare to social security/labour/tax institutions the platform workers' revenues. A foreign platform may escape this obligation. 
declared in a country by the cross-border platform worker for the purpose and/or with the result of evading the law of another country.

This form of undeclared work is an extremely sensitive topic among EU countries. This is often the result of a deliberate strategy by actor(s) with the objective of evading tax obligations and taking advantage of the least costly tax system or the most convenient one. ${ }^{14}$ Undeclared work appears, in this context, an instrument of social dumping. The complexity of EU regulations applying to cross-border situations and the lack of efficient information-sharing processes between countries enhance the risks of this form of undeclared work by platform workers both from the perspectives of social security law (2.2.1) and of labour law (2.2.2).

\subsubsection{Social security issues}

Regulation (EC) No 883/2004 of 29 May 2004 on the coordination of social security systems sets rules for the determination of the social security legislation applicable in cross-border situations. These rules cover also platform workers whatever status they hold in order to perform their activity (employed or self-employed). One key rule for resolving the conflict of law is set out in Article 1l(l): persons are subject to the legislation of a single Member State only. This principle applies even if they perform their activity/activities in more than one Member State.

The first challenge is thus to identify the social security legislation that applies in the situation of cross-border platform work. Even if Regulation (EC) No 883/2004 contains clear conflict rules, their practical implementation is sometimes problematic. This explains the risks of undeclared work: actors may be inclined to evade the law of the competent country where revenues should be declared. Especially the situation where the platform worker works or performs a self-employed activity simultaneously in two Member States will pose problems, but not only.

Let us introduce three situations where undeclared work is likely to arise, show some of the risks run by the platform worker with regard to social security benefits and identify the platforms attitude vis à vis workers' social security coverage.

14 For instance, it is more convenient to pay taxes in its own country or where the worker is already insured. 
2.2.1.1 The worker performs one single self-employed activity in two countries

This situation arises for instance when a freelance platform worker exercises the same activity in two countries for the same platform.

If the platform activity is exercised by the worker under the status of self-employed, which is the common pattern, Article 13(2) of Reg.883/2004 provides that "A person who normally pursues an activity as a self-employed person in two or more Member States shall be subject to: (a) the legislation of the Member State of residence if he/she pursues a substantial part of his/her activity in that Member State; (b) the legislation of the Member State in which the centre of interest of his/her activities is situated, if he/she does not reside in one of the Member States in which he/she pursues a substantial part of his/her activity". This rule raises several issues of interpretation and, therefore, of practical implementation:

When can a platform worker be regarded as "normally pursuing" an activity as a self-employed person in two or more Member States? Marginal and ancillary activities that are insignificant in terms of time and economic return must not be taken into account for the determination of the applicable legislation. This makes it extremely difficult to assess for platform work. When do tasks performed by a platform worker become non-marginal? Should the "waiting time" be counted or should only the actual time for the provision of service be considered? All in all, the demarcation line between non-marginal and marginal activities is very uncertain. This is especially concerning given the fact that platform workers usually operate on the borders of that demarcation line.

How to determine if a "substantial part of activity" is pursued in the country of residence? A 'substantial part of self-employed activity' pursued in a Member State of residence means that a quantitatively substantial part of all of the activities of the self-employed person is pursued there, without this necessarily being the major part of these activities. For the purposes of determining whether a substantial part of the activity of a self-employed person is pursued in a Member State, account must be taken of: the turnover; the working time; the number of services rendered; and/or the income. If in the context of carrying out an overall assessment it emerges that a share of at least $25 \%$ of the above criteria are met, this is an indicator that a substantial part of all the activities of the person is pursued in the Member State of residence. ${ }^{15}$ These multiple and flexible criteria leave a lot of room for interpretation.

15 Article 14 (8), Reg. (EC) 987/2009. 
How to identify the Member State in which the "centre of interest of his/her activities" is situated? The centre of interest of activities should be determined by taking into account all the aspects of that person's occupational activities, notably the following criteria: the locality in which the fixed and permanent premises from which the person concerned pursues his/her activities are situated; the habitual nature or the duration of the activities pursued; the number of services rendered; and the intention of the person concerned as revealed by all the circumstances. In addition to the above criteria, when determining which Member State's legislation is to apply, the assumed future situation in the following 12 calendar months must also be considered. Past performance can be also taken into account as far as it gives a sufficient reliable picture of the self-employed person's activity. Again, these multiple and flexible criteria leave a lot of room for interpretation.

Where should a self-employed platform worker pay his social security contributions when he performs his activity via a platform in at least two countries? As shown above, the answer is far from being clear. In practice, he should be in most cases subject to the social security legislation of the country of residence, but he may be insured in the country of his centre of interests. The flexibility and the lack of accuracy of criteria can encourage a worker to arbitrarily "choose" the country where to be insured although this would not be the competent country under Article 13(2) of Reg.883/2004. In addition, the self-employed platform worker could fail to declare some income received through the platform in the other country. There is a dual risk of undeclared and under-declared work.

Let us take a concrete example where undeclared and under-declared work may occur. A plumber works habitually in the border area of countries A and $\mathrm{B}$ as a self-employed platform worker for a platform established in country A. $\mathrm{He} /$ she resides in country A. In Year 1, he/she draws nearly $40 \%$ of his income from end users located in country A. It means that her/his social security contributions for all income (in country A and in country B) should be paid in country A. The worker fails to declare in country A income received for his/ her activities performed in country B. In Year 2, his/her activity in country A goes way down. A vast majority of his/her clients are now in country B. Does country A remain the country of social security insurance? Yes, if that country remains the centre of his/her interests. However, it appears that social security contributions are much lower in country B than in country A. He/she decides to pay contributions in country $\mathrm{B}$ (without declaring the income received for the activity performed in country A). 
2.2.1.2 The worker performs simultaneously a self-employed and an employed platform activity in two Member States for two platforms

In this situation, a platform worker could exercise his/her activity as a self-employed person in country A for platform A and as an employee in country B for platform B. He/She could also perform his/her employed and self-employed activity in countries A and B for both platforms.

The determination of the social security legislation applicable to a platform worker performing only self-employed platform activities in two countries for two platforms is identical as to the case referred in 2.2.1.1. This is based on the assumption that both activities are classified as self-employed by both countries. Different rules of determination of the legislation applicable would apply if the platform work is classified as self-employed in one country and as a worker or an employee in the other country. Pursuant to Article 13(3) of Regulation 883/2004 indeed, "A person who normally pursues an activity as an employed person and an activity as a self-employed person in different Member States shall be subject to the legislation of the Member State in which he/she pursues an activity as an employed person". It implies that a platform worker who exercises a self-employed activity in country A for platform A and a platform employed activity in country B for platform B is insured for social security in country $B$ where he/she must pay his/ her contributions for all activities, including those performed as self-employed worker in country A.

In practice, risks of undeclared and under-declared work are multiple. It is highly likely that the platform worker pays his/her social security contributions in country A for the self-employed activity carried out there and in country B for the employed activity pursued there. This process (often also the result of the lack of information-sharing between Member States and/or the complexity of the legislation), which goes against the key principle of single legislation applicable, is usual. As a result, there is under-declared work in country B (where all income should be declared). This unlawful behaviour could be encouraged by the fact that, in country $\mathrm{B}$, social security taxes are more expensive than in country A. Also, since no social security contributions are due in country A, the platform worker may fail to declare in country B income drawn in country A. This is a case of under-declared work. Another issue could come from the fact that country A, where the self-employed activity is carried out, may challenge the classification of platform worker and consider that he/she is a worker. ${ }^{16}$ Which

16 This reclassification may lead to the competence of country A if the platform worker resides there and performs a substantial part of his activity in this country. 
country has the power to classify an activity as employed or self-employed? The CJEU held that "a person who is self-employed for the purposes of Title II of the Regulation should be understood to refer to activities deemed such by the legislation applicable in the field of social security in the Member State in whose territory those activities are pursued" ${ }^{17}$ Reclassification of the service contract into an employment contract has indirect consequences for undeclared work.

A concrete example helps to understand the risk of undeclared work. A platform worker performs her activities in country A for platform A and in country B for platform B. She is originally registered as self-employed worker in both countries. She resides in country B. A domestic court from country A rules that the work relationship is reclassified - with retroactive effect - into an employment contract between the worker and the platform. What are the consequences for social security? Before the ruling, the platform worker was probably insured in country B (where she was likely to pursue a substantial activity) where all social security contributions for both activities in both countries had to be paid. After the ruling, since the platform activity carried out in country A is reclassified as an employment relationship, it should be admitted that social security contributions for both activities should be paid - and should have been paid - in country A. Therefore, for the past, she is in an undeclared work situation in country A. For the future, if the worker fails to proceed to the change of country of affiliation - or if she pays social security contributions in country A only for the employed platform activity - she will be undeclared or under-declared there.

\subsubsection{The worker performs two employed / self-employed activities} in two countries, one via a platform

If both activities are self-employed, solutions introduced in point 2.2.1.1 are relevant. For example, the platform worker may be a self-employed graphic artist in country A, running his/her own business, while performing occasionally a self-employed platform work in country B. In principle, the social security legislation of the country of residence where the worker pursues a substantial part of the activity is applicable. Therefore, the same practical issues will arise: When can a person be regarded as "normally pursuing" an activity as a self-employed person in two or more Member States? What is a "substantial activity"? Where is the workers' centre of interest? The risk of a wrong application of

17 Judgment of the CJEU, Case C-340/94, E.J.M. de Jaeck v. Staatssecretaris van Financiën. 
these principles is high. ${ }^{18}$ The platform worker can avoid to pay contributions in the country where he/she should do so, as the following example shows. Let us assume that $\mathrm{Mr} \mathrm{K}$. works as a self-employed platform worker in country A and as a self-employed graphic artist in country B. His activity is marginal in country B where he resides. Social security contributions are much lower in country B than in country A. Mr K. is advised by the platform to claim an Al form $^{19}$ from the local social security institution of country B, establishing that he is insured in that country. Based on the information provided by $\mathrm{Mr}$. K, the local social security institution of country $\mathrm{B}$ considers that a substantial part of activity is pursued in the country of residence and, therefore, issues the Al certificate. He thus pays social security contributions for income received in countries A and B at the low rate of country B. Still, by virtue of Article 13(2) of Reg.883/2004, country A is where all social security contributions should be paid since this is where the centre of his interests is located. Country A institutions may rightly argue that the platform activity is undeclared and, for that purpose, can try to challenge the $\mathrm{Al}$ certificate issued by country $\mathrm{B}$, but with very little chances of success. ${ }^{20}$

Both activities carried out may however be of a different type. For instance, the platform activity in country A is self-employed whereas the activity in country $\mathrm{B}$ is performed under an employment contract. For instance, a worker is a full-time employee in a supermarket in country B and performs a self-employed platform plumbing activity a few hours per week in country A. Article 13(3) of Regulation 883/2004 according to which "A person who normally pursues an activity as an employed person and an activity as a self-employed person in different Member States shall be subject to the legislation of the Member State in which he/she pursues an activity as an employed person", is applicable. It implies that a self-employed platform worker who exercises this activity in country A will be subject to the social security legislation of country B (where he/she has an employment contract) where contributions will have to be paid for all activities. Risks of undeclared work are high as the following example shows. Mrs S. is a frontier worker. She works in country A with an employment contract as a shoe store manager. Three evenings per week, she works in country B (where she resides) as a self-employed bike delivery person for a platform. Social security contributions

18 See point 2.2.1.1.

19 An Al certificate shows which country's social security laws apply to a worker who also works in another country.

20 According to CJEU case law, the Al form is very difficult to challenge, except in exceptional fraudulent cases. See Judgment of the CJEU, Case C 359/16, Altun and others. 
are much lower in country B. According to Regulation (EC) No 883/2004, she is insured in country A where she should pay social security contributions for both activities. However, in order to avoid contributions of country A for the self-employed platform activity carried out in country B, she deliberately misses to claim an Al certificate in country A. Thus it is in country B (where she is registered as self-employed) that she pays the contributions for the self-employed platform activity carried out in that country. She is under-declared in country A.

\subsubsection{Undeclared work and social security benefit related issues}

Undeclared work, understood as income totally or partially declared in a country by the cross-border platform worker for the purpose and/or with the result of evading the law of another country, may have negative consequences on the worker's social security rights. Various situations can be encountered among which unjustified double affiliation in two Member States leading to double payments but not to double benefits. For instance, a self-employed platform worker who works for two platforms in two Member States and who is wrongly affiliated for social security in each country for each platform activity will pay double healthcare contributions even though he/she will receive benefits in only one country.

Other situations to the detriment of the platform worker can be identified. Under-declared activity can indeed lead to the receipt of lower benefits when benefits are calculated according to the amount of contributions. For instance, a self-employed platform worker registered in Member State A and insured in that country, who does not declare additional income drawn in Member State $B$, will receive a lower old age pension if Member State A makes a direct link between the pension amount and the contributions paid (which are based on the income declared). Also, not being affiliated in the right Member State can lead to the loss of social security rights in the country where the worker should have been affiliated. For instance, if the law of that country made the accident at work/occupational disease insurance compulsory, the platform worker will lose the relevant benefits if he/she is a victim of such an unfortunate event. Finally, not being affiliated in the right Member State may place the platform worker in a situation where he/she has no social security coverage at all. Rights may indeed be denied in the country where he/she was wrongly affiliated (after the social security institution discovers the mistake) and in the country where he/she was supposed to be insured (no contributions were paid).

A concrete example can help to understand the risks of loss of social security rights. Claire K., an IT designer, works in countries A and B as a self-employed 
platform worker for a platform established in country A. She resides in country A. In Year 1 , she draws nearly most of her income from end users located in country A. Her social security contributions for all income have to be paid in country A. However, she fails to declare in country A income received in country B. She will therefore lose in country A social security rights which depend on the amount of contributions paid, for instance income replacement benefits in case of sickness. In Year 2, the activity in country A is reduced. Most of her clients are now in country B. Since social security contributions are lower in country B (where benefits are also lower than in country A), she switches to the social security system of country B (without declaring the income received for the activity performed in country A). As a first consequence, she should receive lower benefits not only because she has a less protective insurance but also because she did not declare in country $\mathrm{B}$ all her income. A second consequence could be that, if social security of country B considers that she was wrongly insured in that country (for the reason that the centre of her interests remained in country A), entitlement could be refused.

\subsubsection{The platform's attitude vis à vis workers' social security coverage}

At first glance, the social security legislation applicable to self-employed platform workers is of little interest to platforms. They have no reason to provide assistance or advice to platform workers who are in a cross-border situation and who wonder in which country they should be affiliated for social security. Unless it is required by the law platforms have also no reason to check that all income is declared and social security contributions are rightly paid. They only require a valid registration as a self-employed person.

However, in various situations, the legislation applicable is not neutral for platforms. For instance, since the level of contributions varies according to the countries, platforms may suggest in cross-border situations, without concern for the rules of conflict of law, to opt for the "cheapest" national scheme in order for platform workers to maximise their income. By doing this, workers' net income artificially goes up, reducing the pressure on platforms to increase the fees. Platforms may also wish by various means (see box below) to avoid the affiliation of the platform worker in a Member State where specific legal or conventional social security obligations apply to platforms. Platforms workers can also be encouraged or required to register as self-employed persons in the country where the platform is established (irrespective of the fact that they do not perform their services there), especially if there is no risk of reclassification into an employee status. Indeed, such reclassification is a danger which 
platforms wish to avoid at all costs. Indeed, reclassification entails payment of social security contributions by the platform-employer.

All in all, platform workers may be encouraged (or required) by the platform to register as self-employed workers in the country where the platform is established, notwithstanding the fact that according to rules of conflict of law set out in Regulation 883/2004, they should be affiliated in another country where, possibly, social protection would be more suited to their needs.

\subsubsection{Labour law issues}

Can cross-border platform work lead to undeclared work in the field of labour law? The explanations below could bring an affirmative answer.

Rules set out in Regulation (EC) No 883/2004 for the determination of the social security legislation applicable are not relevant in the field of labour law. Article 8 of Regulation (EC) No 593/2008 of 17 June 2008 on the law applicable to contractual obligations indeed determines the law applicable to a cross-border employment contract. Since platform workers are usually registered as self-employed workers, Article 8 of Regulation (EC) No 593/2008 is in principle not applicable to them. However, as it appears from the case law of some European countries, domestic courts sometimes reclassify the service contract concluded between a platform and a worker into an employment contract when it results from the circumstances than the link of subordination between parties is equivalent to that of an employee and an employer. ${ }^{21}$ What are the impacts of such reclassification for undeclared work?

Since the classification into an employment contract is a preliminary step for the determination of the employment legislation applicable, it belongs to the court which has jurisdiction to address the dispute by applying its own legislation. For instance, if the reclassification is claimed by a platform worker before a country A court, this court will rule the case by applying its own labour law legislation. Pursuant to Article 2l of Regulation (EC) No 1215/2012 of 12 December 2012 dealing with jurisdiction over individual contracts of employment, an employer domiciled in a Member State may be sued before several courts, in particular the lex loci laboris court. ${ }^{22}$ For instance, if a self-employed platform

${ }^{21}$ See, in particular, the French Cour de Cassation ruling of 28 November 2018, case 17-20.079.

22 (a) in the courts of the Member State in which he is domiciled; or (b) in another Member State: (i) in the courts for the place where or from where the employee habitually carries out his work or in the courts for the last place where he did so; 
worker habitually performs his/her activity in country A (where he/she is registered) for a platform established in country $\mathrm{B}$ where he/she occasionally performs his activity, he/she can claim reclassification before a court of country A. That court will decide on the reclassification on the grounds of its own legislation. If the contract is reclassified into an employment contract, the court will then have to decide which law governs the contract. According to Article 8 of Regulation (EC) No 593/2008, it will be either the law chosen by the parties or, in the absence of choice, the law of the country in which or, failing that, from which the employee habitually carries out his work in performance of the contract. In practice, in the example above, if the service contract is retroactively reclassified by a court of country A into an employment contract governed by the labour law of country A (lex loci laboris), the platform worker will find himself/herself in a situation of undeclared work. In similar cases, the reclassification could lead to the situation where the platform worker, who was registered as self-employed worker in country A, is considered to be in an employed relationship governed by the law of country B. For country B, it is likely to be undeclared work. All in all, the contract reclassification process may facilitate the application of a protective labour law system which the registration as self-employed in another country was aiming to avoid.

What would be the impact of a reclassification into an employment contract on the social security status? Let us assume that Mrs. D. is a platform worker registered as a self-employed in country $B$ where the platform is established. She performs her platform activity mainly in country A (where she resides), from time to time in country B. Social security institutions of country B issued an Al certificate, meaning that she is insured in that country where she pays social security contributions. From the social security perspective, she is in a situation of undeclared work in country A where according to Regulation (EC) No 883/2004 she should pay the contributions. She sues the platform before the labour courts of country A. The service contract with the platform is retroactively reclassified by these courts into an employment contract governed by the labour law of country A. From the labour law perspective, she is also in a situation of undeclared work in country A where she should have been declared by the platform-employer.

or (ii) if the employee does not or did not habitually carry out his work in any one country, in the courts for the place where the business which engaged the employee is or was situated. 


\section{FREE MOVEMENT OF SERVICES AND UNDECLARED WORK}

Article 56 TFEU requires the abolition of all restrictions on the freedom to provide services. Even if those restrictions apply without distinction to national providers of services and to those from other Member States, when they are liable to prohibit, impede or render less advantageous the activities of a service provider established in another Member State where it lawfully provides similar services. The freedom to provide services is for the benefit of both providers and recipients of services. ${ }^{23}$

The question is whether rules determining the social security legislation applicable under Regulation (EC) No 883/2004 are always in line with Article 56 TFEU. Two main issues can be brought up in relation to platform workers' undeclared work.

First, rules on the determination of the social security legislation applicable are not adapted to unstable work situations. As shown above, their flexibility and complexity can facilitate situations of undeclared work. From the free movement of services perspective, two difficulties can be highlighted: first, countries may implement strict measures to struggle against this form of undeclared work, for instance in terms of penalties. Their conformity with rules on free movement of services must be assessed. Second, mistakes of social security affiliation leading to undeclared work may lead to financial and other penalties, although the platform worker may not be responsible for the mistakes.

An example shows this issue quite well. Kristina $M$. is employed as a parttime employed waitress in a restaurant of a touristic city of country A where she resides. Income drawn from this job is not sufficient to cover her expenses. As she is living near the border with country B, she registers there as a self-employed in order to work every weekend for a flower delivery platform. After a phone call to a country A local social security institution, she understands that according to Regulation (EC) No 883/2004 she must pay social security contributions in that country for both activities. She sends to the country B local social security institution an Al certificate issued by country A establishing that she is insured in country A. Six months later she is being dismissed by her employer in country A. She receives unemployment benefits from country A. Since she continues her self-employed activity for the platform in country B, she does not know where she is supposed to be insured for social security now. Pursuant to Article 11(2) of Regulation (EC) No 883/2004, persons receiving

23 Judgment of the CJEU, Case C-42/07, Liga Portuguesa de Futebol Profissional and Bwin International Ltd v. Departamento de Jogos da Santa Casa da Misericordia de Lisboa. 
cash benefits because or as a consequence of their activity as an employed or self-employed person are considered to be pursuing the said activity. Does it mean that Kristina M. remains insured in country A during the period she is receiving unemployment benefits, even if she maintains her self-employed activity in country B, or should she switch to country B social security since this is her only country of work? The local social security institution of country B is not able to provide clear answers to that question but after a few months she receives a letter from this institution saying that since she performs platform work in country $\mathrm{B}$ she is in an undeclared situation and must be retroactively affiliated there. She must pay back to country B social security contributions, interests and financial penalties for undeclared work. Since she kept on paying her contributions in country A for the income drawn from the platform activity in country $\mathrm{B}$, she finds herself in a situation of double contributions.

Are European rules imposing frequent change of social security affiliation to self-employed platform workers so complex that they could encourage undeclared work? The determination of the legislation applicable is strictly based on the facts. For workers who have an unstable professional path - frequent alternation of periods of work and unemployment, regular changes of job, simultaneous exercise of two jobs, etc. - this can lead to multiple changes of social security legislation applicable, in particular in border areas. This is especially true for many platform workers for whom the platform work activity is a side or a transitory activity. In the end, the change of social security affiliation processes is so complex and heavy that self-employed platform workers can decide not to declare this activity. The example below is a good illustration of the problems. John is a jobless teacher. He resides in country B where he is actively seeking a job. Near the border, in country A, he works as a self-employed worker every afternoon for a platform which supports school children with their homework. He is therefore insured in country A where he pays social security contributions to the self-employed scheme. After a couple of months, he finds a full-time job in a private primary school near his place of residence in country B. He stops working for the platform. He has to fill out all the paper work to be disaffiliated from country A. He discovers that he will have to keep paying contributions for three months before obtaining retroactive reimbursement. Unfortunately, the school terminates his employment contract after four months. He is jobless and he is not entitled to any unemployment benefit, but he thinks he has a good chance to be hired in a few weeks by another school in country B. In the meantime, he can work again as a self-employed worker for the school help platform in country A, but changing again the social security affiliation, combined with the registration administrative complexity and the duty to pay flat rate contributions for the first six months (like any other new self-employed workers) 
discourages him to do so. Instead, he prefers to use the platform account of a friend of his who also cooperates with the platform.

\section{CONCLUSION}

The existence, the forms and the intensity of undeclared cross-border platform work are largely unknown. At this stage, undeclared cross-border platform work remains a mere assumption that this article tries to explore. However, the combination between the complexity of the EU social law, its ill-adaptation to new forms of work and new work patterns ${ }^{24}$, as well as the specific nature of (cross-border) platform work, makes a broad gap between EU social security coordination rules and their concrete implementation possible. Stakeholders (workers, platforms) may in some cases either be unaware of the rules applicable, may disregard them or voluntarily misapply them.

Further studies should be conducted to have a better understanding of the situation. The matter will be then to assess whether relevant EU rules, in particular social security coordination regulations, are adapted to the cross-border platform work activity or if their revision should be considered. It is indeed necessary to ensure that, in transnational cases, platform workers be provided a fair and efficient social security coverage (and pay their contributions in the right EU country on the basis of their overall income) as well as protective work-related rules. These remarks concur with the on-going debates at European level on the possible need for specific EU social law tools for platform workers. ${ }^{25}$

24 In the area of social security see Jorens, Y.; Lhernould, J.-Ph.; Fillon, J.-Cl.; Roberts, S.; Spiegel, B., Towards a new framework for applicable legislation, European Commission, trESS network, 2008; Jorens, Y.; Fillon, J.-Cl.; Spiegel, B.; Strban, G., Key challenges for the social security coordination Regulations in the perspective of 2020, European Commission, trESS network, 2013.

25 In the context of social security, see Strban, G.; Carrascosa Bermejo, D.; Schoukens, P.; Vukorepa I., Social security coordination and non-standard forms of employment and self-employment: Interrelation, challenges and prospects, European Commission, MoveS network, 2018. Also see O’Brien, C.; Spaventa, E.; De Coninck, J., The concept of worker under Article 45 TFEU and certain non-standard forms of employment, European Commission, FreSsco network, 2015. 


\section{BIBLIOGRAPHY}

\section{Studies and articles}

European Commission, European Semester Thematic Factsheet on Undeclared Work, https://ec.europa.eu/info/sites/info/files/file_import/european-semester_thematic-factsheet_undeclared-work_en.pdf

European Commission, Special Eurobarometer 402 "Undeclared Work in the European Union", March 2014.

European Economic and Social Committee, Impact of digitalisation and the on-demand economy on labour markets and the consequences for employment and industrial relations, Publications Office of the European Union, Luxembourg, Brussels, 2017, https://www.eesc.europa.eu/sites/default/files/resources/docs/qe-02-17763-en-n.pdf.

Eurofound (), Automation, digitalisation and platforms: Implications for work and employment, Publications Office of the European Union, Luxembourg, 2018, https://www.eurofound.europa.eu/sites/default/files/ef_publication/field_ef_ document/ef18002en.pdf.

Eurofound, Employment and working conditions of selected types of platform work, Publications Office of the European Union, Luxembourg, 2018, https://www. eurofound.europa.eu/publications/report/2018/employment-and-workingconditions-of-selected-types-of-platform-work.

Florisson, R.; Mandl, I., Platform work: Types and implications for work and employment, Literature review, Eurofound, 2018, https://www.eurofound.europa.eu/ sites/default/files/wpef18004.pdf.

Jorens, Y.; Lhernould, J.-Ph.; Fillon, J.-Cl.; Roberts, S.; Spiegel, B., Towards a new framework for applicable legislation, European Commission, trESS network, 2008.

Jorens, Y.; Fillon, J.-Cl.; Spiegel, B.; Strban, G., Key challenges for the social security coordination Regulations in the perspective of 2020, European Commission, trESS network, 2013.

Lhernould, J-Ph., Employment and working conditions of selected types of platform work: National context analysis France, Eurofound, 2018, https://www.eurofound. europa.eu/sites/default/files/wpef18054.pdf.

O’Brien, C.; Spaventa, E.; De Coninck, J., The concept of worker under Article 45 TFEU and certain non-standard forms of employment, European Commission, FreSsco network, 2015.

Pesole, A.; Urzí Brancati, M. C.; Fernández-Macías, E.; Biagi, F.; González Vázquez, I., Platform Workers in Europe, EUR 29275 EN, Publications Office of 
the European Union, Luxembourg, 2018, https://publications.jrc.ec.europa.eu/ repository/bitstream/JRC112157/jrcl 12157_pubsy_platform_workers_in_europe_science_for_policy.pdf.

Popescu, M.; Cristescu, A.; Stanila, L.; Vasilescu, M., Determinants of undeclared work in the EU Member States, Procedia Economics and Finance, vol. 39, 2016, pp. 520 - 525, doi: 10.1016/S2212-5671(16)30294-5

Strban, G.; Carrascosa Bermejo, D.; Schoukens, P.; Vukorepa, I., Social security coordination and non-standard forms of employment and self-employment: Interrelation, challenges and prospects, European Commission, MoveS network, 2018.

\section{Case law}

CJEU, Case C 359/16, Altun and others

CJEU, Case C-340/94, E.J.M. de Jaeck v. Staatssecretaris van Financiën

CJEU, Case C-384/93, Alpine Investments BV v. Minister van Financiën

CJEU, Case 279/80, Alfred John Webb.

CJEU, Case C-243/01, Piergiorgio Gambelli and Others

CJEU, Case C-42/07, Liga Portuguesa de Futebol Profissional and Bwin International Ltd

French Cour de Cassation, 28 November 2018, case 17-20.079. 


\section{Sažetak}

\section{Jean-Philippe Lhernould*}

\section{PREKOGRANIČNI PLATFORMSKI RAD UNUTAR EU-a: PRIKRIVANJE PROBLEMA NEPRIJAVLJENOG RADA}

Većina dostupnih podataka upućuje na to da je neprijavljeni rad uglavnom prisutan u području građevinarstva, obnove i popravaka, čišćenja, čuvanja djece i brige za starije $i$ nemoćne. Mnogi od tih sektora prevladavaju u platformskoj ekonomiji i odnose se na usluge koje platformski radnici pružaju lokalno ili na mjestu korisnika usluge.

Cilj je ovog rada istražiti specifična pitanja koja se javljaju u vezi s prekograničnim platformskim radom glede neprijavljenog rada shvaćenog kao prihod koji je u cijelosti ili djelomično prijavljen u jednoj zemlji s ciljem, odnosno s rezultatom, izbjegavanja primjene pravila druge zemlje.

Složenost pravila EU-a koja se primjenjuju na prekogranične situacije i nedostatak učinkovite razmjene informacija među zemljama članicama povećava rizike s obzirom na ovaj oblik neprijavljenog rada platformskih radnika $i$ iz perspektive socijalnog prava $i$ radnog prava. Glede socijalnog prava, glavni je izazov identificirati mjerodavno pravo socijalne sigurnosti i pravna pravila koja se primjenjuju u slučaju prekograničnog platformskog rada. Premda Uredba (EC) 883/2004 sadržava jasne odredbe o rješavanju sukoba prava, njihova je praktična primjena ponekad vrlo problematična. To objašnjava i rizike neprijavljenog rada: sudionici mogu biti skloni, iako mogu to i nenamjerno činiti, izbjegavanju primjene prava države u kojoj bi prihodi trebali biti prijavljeni. Problemi mogu posebno nastati, iako ne i samo tada, u situaciji kada je platformski radnik zaposlen ili pak obavlja posao u okviru samostalne djelatnosti (samozapošljavanja) istodobno u dvije zemlje članice. S obzirom na radno pravo, rizik neprijavljenog rada posebno se javlja u slučajevima moguće reklasifikacije prekograničnog platformskog rada u radni odnos koji osoba inače obavlja kao samozaposlena. Ako bi ugovor o uslugama retroaktivno bio ocijenjen od strane domaćeg suda kao odnos zasnovan na ugovoru o radu na koji treba primijeniti domaće pravo, platformski radnik koji je registriran kao samozaposlena osoba mogao bi se naći u situaciji neprijavljenog rada.

U radu se raspravlja i o pitanju jesu li odredbe kojima se odreduje mjerodavno pravo socijalne sigurnosti prema Uredbi (EC) 883/2004 u skladu s pravilima o slobodnom kretanju usluga. Naime, čl. 56. UFEU-a zahtijeva ukidanje svih zapreka slobodnom

* Dr. sc. Jean-Philippe Lhernould, profesor Pravnog fakulteta Sveučilišta u Poitiersu, 2 rue Jean Carbonnier - Bât A 1 - TSA 81100, 86073 Poitiers Cedex 9, Francuska; jean-philippe.lhernould@univ-poitiers.fr;

ORCID ID: orcid.org/0000-0001-7871-1353 
pružanju usluga te se s obzirom na to upozorava na dva moguća problema. Prvo, države mogu donijeti stroge mjere u borbi protiv neprijavljenog rada, primjerice propisati određene kazne, te je stoga potrebno procijeniti njihovu uskladenost s pravilima o slobodi kretanja usluga. Drugo, pogreške glede određenja mjerodavnog pravnog sustava socijalne sigurnosti mogu dovesti do neprijavljenog rada te posljedično do financijskih i drugih kazni iako platformski radnik možda nije bio odgovoran za te pogreške. Posljednje je analizirano pitanje jesu li pravna pravila EU-a prema kojima može doći do čestih promjena u pripadnosti određenom sustavu socijalne sigurnosti samozaposlenih osoba koje obavljaju platformski rad previše kompleksna, čime potencijalno potiču neprijavljeni rad.

Ključne riječi: prekogranični platformski rad, neprijavljeni rad, Uredba 883/2004, Uredba (EC) 593/2008, sloboda kretanja usluga 